\title{
Obituary: Professor Adam Matthew Neville CBE
}

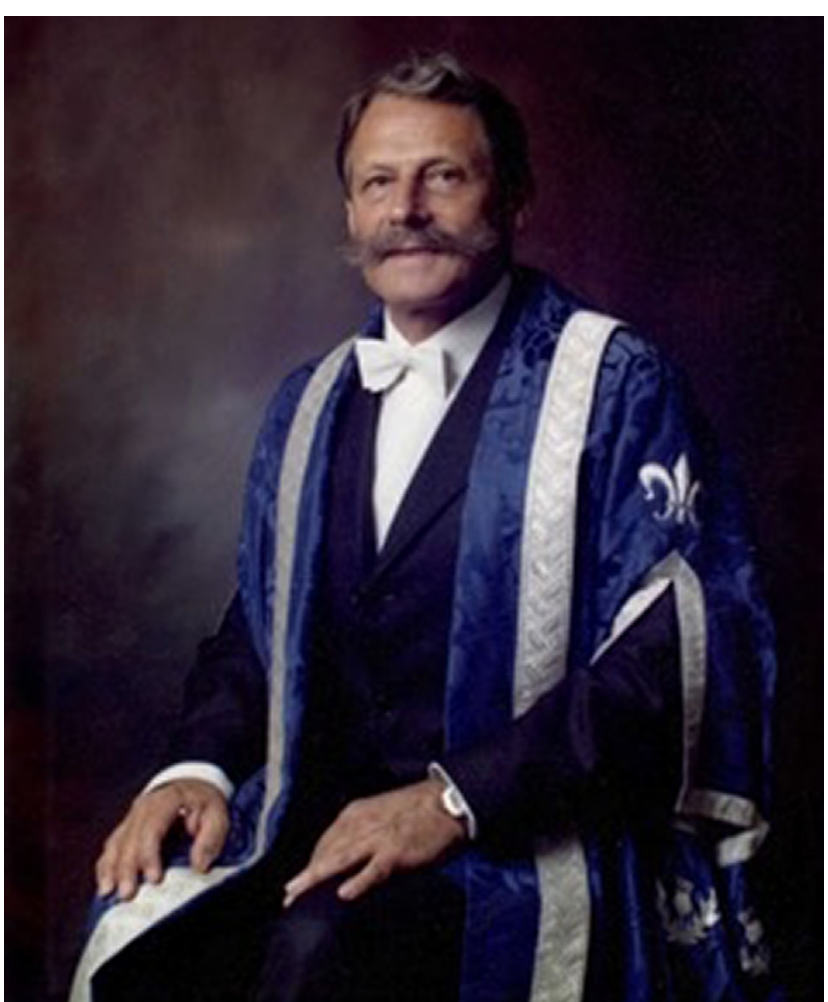

Professor Adam Matthew Neville CBE, 1923-2016

It is with great regret that the Magazine of Concrete Research panel have to record the death of Professor Adam Matthew Neville who died on the $6^{\text {th }}$ of October in London aged 93.
He was born Adam Meciej Lisocki in Krakow, Poland, in 1923. At the age of 15, he won the British Council scholarship, and as a consequence spent a year in England. When the Second World War broke out he tried to flee Poland but was captured by the Russians and spent the rest of war either in incarceration or, once he was released, as a soldier. During this time he was awarded the Cross of Monte Cassino and the Polish Cross of Valour.

After he demobbed he returned to his studies and went on to graduate from Queen Mary College, the University of London, with a First Class Honours engineering degree. He had an illustrious career, specialising in concrete construction, with particular focus on high alumina cement-based concretes; providential in predicting failures that occurred later. He accepted positions from all over the world including New Zealand (at Christchurch University), Nigeria (as the first Dean of Engineering at the Nigerian College of Technology in Zaria) and Canada (as first Dean of Engineering at the University of Calgary). In total, he visited more than 250 islands and countries. He was also a champion of women in engineering. When he was the Head of the Civil Engineering Department at the University of Leeds there were more female students in his department than the total in all of the rest of the UK's universities. He was a prolific researcher and writer. He was author of some 11 books and 250 articles but is perhaps best known for the book 'Properties of Concrete' that was written in 1963 (known as 'Neville's concrete bible'). The book was republished in its fifth edition as recently as 2011 .

After his retirement from academia in 1987, he became a consultant and expert witness. He received many honours in open recognition of his achievements including a DSC(Eng), a CBE for services to Technology and Science in 1994, as well as an honorary Doctor of Laws from the University of Dundee, where an annual lecture is also named after him. In 2008 he received the Royal Academy of Engineering's Sustained Achievement Medal.

Professor Neville was unique and lived a social as well as technical life to the full and will be very much missed by colleagues and those who knew him by his achievements. He is survived by his wife, Mary, two children and five grandchildren. 